\title{
Competition Law Benefits, Application \& Monitoring: Reviewing Practices In UK, USA And Australia \& Possible Benefits For Bangladesh
}

\author{
${ }^{1}$ Munshi Samaduzzaman, ${ }^{2}$ Fazluz Zaman \\ ${ }^{1}$ Adjunct lecturer, Central Queensland University, Australia , ${ }^{2}$ Adjunct lecturer, University of New South Wales, \\ Australia
}

\begin{abstract}
The paper focuses on the application, monitoring, and benefits of the competition law. The topic that covers in the entire paper is mainly focuses on the importance of the competition law that particularly applies in the consumer protection that has been established in order to promote the balance and fairness in the economic consumption and spending. This paper will present the understanding on the competition law and policy that aims to protect the consumers and provide the scenarios in competition laws that is mostly based on UK, USA, and Australia. It is important for the study to discuss such matter in order to recognize the effectiveness of the policy and its applicability in trading and commerce. In addition, the aims to determine the impact of the competition law in developing countries.
\end{abstract}

\section{Introduction}

The competition law and its application is generally designed by different countries in order to prevent any harmful transactions and thus protecting the consumers from the different business organizations that tends to take advantage within the market (Lande, 2004). Upon the application of the competition policy, the monitoring of its implementation is also important in order to plan the long-term benefits. In general, the consumer protection policy creates an environment whereby the clients, customers, and consumers receive satisfaction from the delivery of goods and services needed by them. Good governance requires efficiency, effectiveness, ethics, equality, economy, transparency, accountability, empowerment, rationality, impartiality and participation of citizens. The concern of consumer protection is to ensure fair trade practices; quality of goods and efficient services with information to the consumer with regard to quality, quantity, potency, composition and price for their choice of purchase. Thus, proper and effective implementation of consumer protection law promotes good governance.

\section{Competition Law And Its Benefits In UK, USA, Australia}

This section will review the benefits of having Competition Law in Retail Business Sector in different countries like in UK, USA, and Australia. Competition law from these countries might be different from one another and therefore, there are topics that can be discussed related on the competition law, particularly on the benefits that it may create.

2.1. Price fixing and making extraordinary profits over the general consumer's is a major issue? How it can be prevented?

Price fixing, as according to Street Law's Antitrust Lessons (2006) is_"an illegal arrangement among competitors to agree on and set prices for products (e.g. if all the manufacturers of bicycles agreed to charge the same prices). Price-fixing can also be achieved by agreeing to reduce or restrain output (e.g., OPEC does not set a price for oil, but rather arranges for the members to limit how much oil each will sell into the market)."

By the term "illegal", it only means that the price fixing is not promoted openly to the public. In some case, people might think that it should be punishable by law. However, there are cases wherein this idea is appropriate because of the economic constraints and other circumstances (Baker, 2003). Like the given example pertaining to the oil price and other related products. There is no price indicator or projections on what would be the level of oil production, the selling price is hard to foresee or can be unpredictable (Grant \& Thille, 2001). Furthermore, the influence of other circumstances like the war in Middle East - which is one of the biggest suppliers of oil and gas and etc. - can directly affect the price range of oil within the global market (Connor, 2001; 2005).

But despite of the idea that price fixing, it is unfair for the consumers and it can be an issue especially when the price of a certain product climbs up into an amount unexpectedly. There are recognized consequences in the welfare due to the price fixing (Crandall \& Winston, 2003; Beckmann, 2004). First is the experience of 
unfair competition particularly when this is interpreted through the economic theory of demand and supply. The demand and supply equilibrium can be undermined and there is no determination whether there is a balanced distribution or not. Second reason on why it can become a consumer issue is that because, it has a potential to go higher on prices and create less choice. Third is having the divergence from pareto optimal outcome, distributional concerns (such as the demand and supply theory) and the consumers will take a shift of consumer surplus to producer surplus. There is also an explanation of deadweight loss and somehow the difficulties in interpreting the regulation (Clarke \& Evenett, 2003).

However, this unfair situation can be prevented with the help of the countries specified adoption of law on price fixing and consumer rights. In Australia, this is called the Competition and Consumer Amendment Act.

\subsection{Review the Competition Laws that are practiced in UK, USA and Australia? How they are protecting} customers in the retail business sector?

Each country as well as in most major advanced economies, the importance of Competition Laws heightened and are considered to be the economic charter or economic constitution of the market oriented economy. According to the Australian Competition Law, the Competition and Consumer Amendment Bill (No. 1) 2011 (Bill) amends the Competition and Consumer Act 2010 (CC Act) to further the objective of the CC Act by addressing anti-competitive price signalling and information disclosures. This bill is an anti-competitive price signalling and information disclosures are communications between competitors which facilitate prices above the competitive level and can lead to inefficient outcomes for the economy and reduce wellbeing for consumers. They fall short of cartel behaviour but can have similar effect. Anti-competitive price signalling and information disclosures can occur as part of a wider cooperation agreement, or as a stand-alone practice absent of an explicit cartel arrangement. The Bill further safeguards competition in Australian markets by introducing two prohibitions directly targeting anti-competitive price signalling and information disclosures. The prohibitions will apply to classes of goods or services that are prescribed by regulations.

In general, the promotion of consumer welfare is the common goal of consumer protection and competition policy. At the root of both consumer protection and competition policy is the recognition of an unequal relationship between consumers and producers. Protection of consumers is accomplished by setting minimum quality specifications and safety standards for both goods and services and establishing mechanisms to redress their grievances. The objective of competition is met by ensuring that there are sufficient numbers of producers so that no producer can attain a position of dominance. If the nature of the industry is such that dominance in terms of market share cannot be avoided, it seeks to ensure that there is no abuse on account of this dominance. Competition policy also seeks to forestall other forms of market failure, such as formation of cartels, leading to collusive pricing, division of markets and joint decisions to reduce supply. Mergers and acquisitions also need to be regulated as they reduce competition.

Based on the Competition Law, the policy being applied and basically in order to protect the consumer. This means that even in the movement of the commerce and trade, the concept of consumer protection in an important even in retailing business sector (Bajari \& Ye, 2003). The concept of consumer protection against exploitation by the trade and retailer with respect to quality, short weight, measurement and adulteration of goods are applied in countries like UK, USA, and in Australia in order to regulate the competition. The action of the government in safeguarding the interest of the consumers and is widely acknowledged that the level of consumer awareness and protection is a true indicator of development of the country and progressiveness.

Taking note the experience of United States (Crespi \& Chacon-Cascante, 2004) in creating the balance in competition, the study of Thanitcul (2008) focuses primarily on the small and medium sized (SMEs) business which includes the retailing. Against the large retailers, small retailers seem to restraint competition and appear not to be permissible in the competition law. However, due to the Sherman Act of 1891, the ultimate goal which is maintaining and promoting the free and fair competition can be emphasized. Therefore, aside from protecting the consumers, the government and competition law is aimed to also protect the competitors (Granitz \& Klein 1996). The policy focuses on the healthy promotion of competition among the business entrepreneurs because it has ultimate benefits of consumers.

As a solution in protecting the consumers, there are measures that has been adopted in these economies that can improve the balance in between the SMEs protection (in particular) and as well as maintaining the free and fair completion. Therefore, the following are specifically adopted and practiced in order to protect the consumers' welfare which has been taken from the study of Thanitcul (2008).

- To impose heavier tax burden on large retailers.

- To keep large retailers from further expansion by the use of zoning regulations. These are measures adopted and still in force in a number of European nations.

- To keep large retailers from expanding into traditional markets by the use of the large scale retail store law.

- To keep large retailers from expanding into traditional markets by the use of the competition law.

- To regulate the conduct on unjust low price or predatory pricing of large retailers by using competition law. This might be helpful in mitigating the price war between small retailers and large retailers. In other words, 
it is meant to help small retailers who have horizontal competitive relationship with large retailers to compete better with large retailers.

- To regulate the conduct on abusing of bargaining position of large retailers by the use of competition law. This might be helpful in mitigating the adverse effect on SMEs suppliers. In other words, it is meant to help weak SMEs suppliers who have vertical relationship with powerful large retailers from taking advantage out of their business relation.

\section{Competition Law Application \& Monitoring To Improve Current Situation In Bangladesh}

No competition law Exists in Bangladesh. Competition Law can offer consumer's quality goods and services at a competitively cheaper price. Due to population growth and geographic position - Bangladesh is emerging as potential retails market both domestically and internationally. Due to not having competition law, Bangladesh is facing problem like anti-competitive cartels, hoarding and black marketing of commodities, etc.

How competition Law can effectively prevent those problems in Bangladesh? After endorsing competition law - how Bangladesh can best monitor the situation to make continuous improvement of the process?

Bangladesh is primarily a homogenous country and more importantly, Bangladesh is a liberal democracy with a population of about 130 million, living in total harmony for thousands of years. The geographical location of the country is ideal for global trade with access to international sea and air route. Apart from that, the country is endowed with abundant natural resources like natural gas, water and fertile soil etc. Although Bengali is the official language, English is also widely used and spoken (Khaleque, 2006). Because of these characteristics of the country, there are many expectations towards it improvement and hidden potentials.

However, despite of the potentials that Bangladesh has, there are issues emerged and serves as hurdle towards the total development such cases as unfair competition, consumer production, monopolies, anti-trust etc. Bangladesh should adopt a law or regulation in which it can protect the future by emphasizing a strong possibility with the changes in the structure and behaviour of the market (Eichenwald, 2000). One cannot therefore, overlook the issues surrounding competition policy and the like. There is not much research or published materials on the market behaviour in Bangladesh which may provide useful guide to formulation of competition policy and law. As an answer to those problems, Bangladesh undertook the competition advocacy that ultimately aims for the future policy and protects the interests of the consumers. However, while aiming for that in the context of Bangladesh, the matter of protection of both competition and the competitors need also to be kept in mind (Granitz \& Klein, 1996).

The ultimate object of competition policy is to protect consumer as well as producers and ensure safeguarding of public interest. There is no law in Bangladesh to provide protection against the injuries caused by monopolies and unfair trade practices. It is understood that Government of Pakistan had passed an anti-trust legislation in 1970 but it was not duly notified prior to the war of Independence of Bangladesh, hence in this country there was no continuity of it and it was possibly forgotten. Today the available laws in Bangladesh that concern one way or the other the interests of consumers appear to include the following according to Khaleque (2006).

a. The Control of Essential Commodities Act. 1956

b. The Pure Food Stuff Ordinance, 1959

c. The Trade Mark Act, 1940

d. Essential Commodities Price \& Bond Ordinance, 1970

e. Weights and Measures Ordinance, 1961 and its amendment of 1982

f. Drug Control Ordinance. 1983

g. Breast Milk Substitutes Ordinance, 1983

With this, the research and secondary studies that can be produced should focus more on the provisions of the existing laws \& rules really effective in order to ensure fair price and quality and to prevent injury to consumers interests and to arrange for proper coordination amongst various implementing agencies (Werden, 2004). Furthermore, it can also appropriate to conduct the studies based on how other countries protect the interests of the consumers and monitoring the competition of the business in different perspective (Khaleque, 2006). The regulatory bodies should be also independent in order to avoid any biasness in the decision. But the most important thing in establishing the consumer protection bill and competition is to look on what situation is should fit. Not only by looking on the experiences of other countries, the Bangladesh should also consult their own experience to interpret their comprehensive law and regulations. There should be an extensive monitoring on the regulations being implement to ensure that policies are being followed. 


\section{Conclusion}

Competition policy plays a significant role in every country. Indeed, it does not provide the balance and fair trade among the retailers and other businesses but also protects the consumers against any other abuse of other business organizations. The presence of such uncertainty enables the country in implementing the policy against the sudden price hike and means that the government is serious and concern in protecting the people towards sustainability. Despite of the occurrences of difficulties, it is still encouraged that each country, either developing or developed countries, should provide the adequate to promote their interest in economic development. In addition, the idea that the competition policy can create benefits such as good governance is a good indication that the organization is willing to change toward the betterment and development.

However in the case of Bangladesh, it is advice that the government should be open on debate in imploring the need to determine the establishment of the consumer policy and led the economy to be open with the global economy. Therefore, it is important that the country will provide the adequate research to produce the relative opinions towards the issue. It is very vital to look on the loopholes that can greatly affect the laws, rules, and practices. It is also important that in creating a policy, the policymakers should keep in mind the importance and rights of the consumers.

\section{References}

[1] Lande, RH 2004,'Why Antitrust Damage Levels Should Be Raised', Loyola Consumer Law Review, vol. 16, no. 4, pp. 326-329.

[2] Street Law's Antitrust Lessons 2006, What are price fixing and collusion? Available from: <http://www.fairfightfilm.org/lessons/lesson3.pdf>. [05 January 2012].

[3] Baker, JB 2003, 'The Case for Antitrust Enforcement', Journal of Economic Perspectives, vol. 17, no. 4, pp. 27-50.

[4] Grant, H \& Thille, H 2001, 'Tariffs, Strategy and Structure: Competition and Collusion in the Ontario Petroleum Industry, 18701880', Journal of Economic History, vol. 61, pp. 390-413.

[5] Connor, JM 2001, Global Price Fixing: Our Customers are the Enemy, Boston: Kluwer Academic.

[6] Connor, JM 2005, 'Global Antitrust Prosecutions of Modern International Cartels', Journal of International Competition and Trade, forthcoming, pp. 50.

[7] Crandall, RW \& Winston, C 2003, 'Does Antitrust Policy Improve Consumer Welfare? Assessing the Evidence', Journal of Economic Perspectives, vol. 17, no. 4, pp. 1-26.

[8] Beckmann, M 2004, 'Art Auctions and Bidding Rings: Empirical Evidence from German Auction Data', Journal of Cultural Economics, vol. 28, pp. 125-141.

[9] Clarke, JL \& Evenett S 2003, 'The Deterrent Effects of National Anticartel Laws: Evidence from the International Vitamins Cartel', Antitrust Bulletin, vol. 48, pp. 289-726.

[10] Australian Competition Law 2011, Competition and Consumer Amendment Act (No 1) 2011, Available from: <http://www.australiancompetitionlaw.org/legislation/2011 pricesignalling.html> . [05 January 2012].

[11] Bajari, P \& Ye, J 2003,' Deciding between Competition and Collusion', Review of Economics and Statistics, vol. 85, pp. 971-989.

[12] Crespi, JM \& Chacon-Cascante, A 2004, 'Do U.S. Marketing Orders Have Much Market Power? An Examination of the Almond Board of California. Agribusiness', An International Journal, vol. 21, pp. 1-16.

[13] Thanitcul, S 2008, 'SMEs and Competition Law: A Case Study on Suppliers of Goods to Large Retail Stores', Journal of International Cooperation Studies, vol. 15, no. 3.

[14] Granitz, E \& Klein. B 1996, 'Monopolization by "Raising Rivals' Costs": The Standard Oil Case', Journal of Law and Economics, vol. 39, pp. 1-47.

[15] Khaleque, MH 2006, Competition Policy and Law: Bangladesh's Perspective, Available from: <http://siteresources. worldbank.org/INTCOMPLEGALDB/Resources/ComPolandLawBangladesh.pdf>. [05 January 2012].

[16] Eichenwald, K 2000, The Informant: A True Story, New York: Broadway Books.

[17] Werden, GJ 2004, 'Economic Evidence on the Existence of Collusion: Reconciling Antitrust Law with Oligopoly Theory', Antitrust Law Journal, vol. 71, pp. 719-800. 